\title{
Validation of the Papo Reto game as a pedagogical device of adolescent in the context of sexuality
}

\author{
Validação do jogo Papo Reto como um dispositivo pedagógico para adolescentes no contexto da sexualidade \\ Validación del juego Papo Reto como un dispositivo pedagógico para adolescentes en el contexto de la sexualidad
}

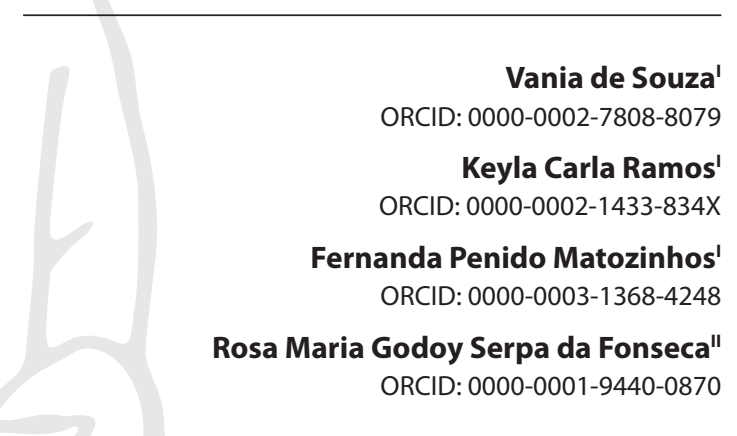

'Universidade Federal de Minas Gerais. Belo Horizonte, Minas Gerais, Brazil.

"Universidade de São Paulo. São Paulo, São Paulo, Brazil.

How to cite this article: Souza V, Ramos KC, Matozinhos FP, Fonseca RMGS. Validation of the Papo Reto game as a pedagogical device of adolescent in the context of sexuality. Rev Bras Enferm. 2020;73(Suppl 4):e20190052. doi: http://dx.doi.org/10.1590/0034-7167-2019-0052

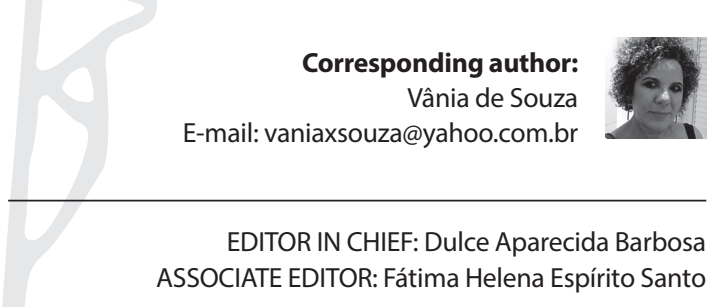

Submission: 06-04-2019

Approval: 03-23-2020

\begin{abstract}
Objectives: to validate the online game Papo Reto to approach sexuality in adolescence, according to the categories: Technical and esthetic aspects; Dynamics; Playfulness; Content; Pedagogical potential. Methods: a descriptive quantitative study with online collection instrument, composed of the 5 categories with 85 variables. Twelve judges participated in the assessment. Data treatment used Stata 14.0, and analysis used Content Validity Index (CVI) and Cronbach's Alpha ( $a$ ). Results: the a coefficient showed very high reliability $(a=0.95)$ for the Playfulness category, and high reliability $(a \geq 0.75)$ for the others. Of the 85 variables, 84 were validated by at least one of the judges, with $\mathrm{CVl}=1$. Although the game has been validated in 5 categories, variations in the Alpha (a) and CVI coefficients proved to be fundamental for new productions Conclusions: the diversity of the methods adopted contributed to the reliability of the result. The analyzed variables expressed the adequacy of the game.

Descriptors: Validation; Adolescent; Sexuality; Game; Pedagogical Device.
\end{abstract}

\section{RESUMO}

Objetivos: validar o jogo online Papo Reto para abordagem da sexualidade na adolescência segundo as categorias: Aspectos técnicos e estéticos; Dinâmica; Ludicidade; Conteúdo; Potencial pedagógico. Métodos: estudo quantitativo descritivo com instrumento de coleta online, composto das 5 categorias com 85 variáveis. Participaram da avaliação 12 juízes. Tratamento dos dados feito com uso do Stata 14.0 e análise pelo Índice de Validade de Conteúdo (IVC) e Alfa de Cronbach (a). Resultados: o coeficiente a apresentou confiabilidade muito alta $(a=0,95)$ para a categoria Ludicidade, e confiabilidade alta $(a \geq 0,75)$ para as demais. Das 85 variáveis, 84 foram validadas por pelo menos um dos juízes com IVC=1. Embora o jogo tenha sido validado nas 5 categorias, variações no coeficiente Alfa (a) e IVC revelaram-se fundamentais para novas produções. Conclusões: a diversidade dos métodos adotados contribuiu para confiabilidade do resultado, e as variáveis analisadas expressaram a adequação do jogo. Descritores: Validação; Adolescente; Sexualidade; Jogo; Dispositivo Pedagógico.

\section{RESUMEN}

Objetivos: validar el juego en línea Papo Reto para abordar la sexualidad en la adolescencia según las categorías: Aspectos técnicos y estéticos; Dinámica; Lúdico; Contenido; Potencial pedagógico. Métodos: un estudio descriptivo cuantitativo con instrumento de recolección en línea, compuesto por 5 categorías con 85 variables. Doce jueces participaron en la evaluación. El procesamiento de datos se realizó con Stata 14.0 y el análisis con el Índice de Validez de Contenido (IVC) y el Alfa de Cronbach (a). Resultados: el coeficiente a mostró una confiabilidad muy alta $(a=0.95)$ para la categoría Lúdico, y una alta confiabilidad ( $a \geq$ 0.75) para las demás. De las 85 variables, 84 fueron validadas por al menos uno de los jueces con IVC $=1$. Aunque el juego fue validado en las 5 categorías, las variaciones en los coeficientes Alpha (a) y IVC demostraron ser fundamentales para las nuevas producciones. Conclusiones: la diversidad de los métodos adoptados contribuyó a la fiabilidad del resultado, y las variables analizadas expresaron la idoneidad del juego.

Descriptores: Validación; Adolescente; Sexualidad; Juego; Dispositivo Pedagógico. 


\section{INTRODUCTION}

In recent years, electronic games have increasingly become a daily component of mass entertainment, encouraging new cognitive abilities. Undoubtedly, games have enabled the involvement, especially of young people, in complex social networks, building and exploring new knowledge ${ }^{(1)}$.

In educational and health institutions, in which the use of games is also on the rise, there is still a paradoxical relationship between its primarily educational purpose - with the seriousness attributed to the acquisition of knowledge - and the characteristic and essential playfulness of games ${ }^{(2)}$. This paradoxical issue can find an alternative when the game is guided by the junction between the dynamic play and the educational activity, without one overlapping the other ${ }^{(3)}$. It is also important that to mention that formal education, with prior knowledge and content expectations, does not become a teaching bond ${ }^{(4)}$, with the game constituting a free strategy, with a challenging environment and without pre-conceived definitions.

In the health area, for instance, it is common for games and other educational materials to be aimed at conducting knowledge that ends in the transmission of information, in order to achieve a behavior considered ideal or healthy. In this perspective, the educational process becomes vertical, with little or no opening to the new, to the rupture of crystallized concepts, to the invention and to the creation of new modes of subjectification ${ }^{(4)}$.

The online game was developed to address the themes "sex" and "sexuality in adolescence". It aimed to create a pedagogical device that would allow a critical-reflective and autonomous positioning of adolescents aged 15 to 18, in the affective-sexual field, focusing on their inventive, autonomous and playful capacity ${ }^{(5)}$.

The device is conceived here as

a kind of skein or skein, a multilinear set, composed of lines of a different nature (...) [Unraveling its lines] in each case is to build a map, map, traverse unknown lands (...) [Such lines] establish the swing between seeing and saying, they act as arrows that do not cease to intertwine things and words, that do not cease to lead the battle ${ }^{(6)}$.

Thinking of the game as a device is to place it in the condition of heterogeneous assembly that produces innovations that generate events and developments through the updating of virtualities. In the device, multilinear elements and forces connect to overcome the limits of the instituted territories and move in the direction of absolute difference. With this movement, the production of new realities is ensured, because by opening up the unfinished things, what is about to be done is qualified. The device "plays" with the production of truths in favor of life, taking it into its creative power, to alter different ways of existing ${ }^{(6)}$.

The game Papo Reto proved to be a potential alternative to establish a problematic aspect, capable of mobilizing players in their desires and experiences. As a simulator of realities, the game mimics a city with settings such as home, school, internet, hang out, and street. High school adolescents debate everyday situations that lead to decision making, sharing with their peers about their ways of thinking and acting, without the interference of adults ${ }^{(5)}$. The settings are unlocked progressively by the players' scores, led to the ranking of the most scored based on the level of interaction achieved.

Game creation went through the game design stages (Game Design); analysis by the Consultation Group (CG); Game Design restructuring; finalization and validation by the Specific Group (SG). The GC had the participation of professors, researchers and experts in one or more of the following fields of activity: sexuality, adolescence, sex, games, performing arts and game design ${ }^{(5)}$. This paper corresponds to the stage of validation of the game by the SG.

\section{OBJECTIVES}

To validate the game Papo Reto (freely translated as Real Talk) in terms of the following aspects: technical and esthetic, dynamics, playfulness, content and pedagogical potential, to address the theme "sexuality in adolescence".

\section{METHODS}

\section{Ethical aspects}

The project was approved by the Research Ethics Committee of the Universidade Federal de Minas Gerais.

\section{Study design, period and location}

This is a descriptive-analytical study, guided by the GREET ${ }^{(7)}$ tool, carried out in 2016 and 2017, in Belo Horizonte, Minas Gerais.

\section{Population, inclusion and exclusion criteria}

Twelve judges participated, selected and included for a minimum doctoral degree and acting in one or more areas of affinity with the game as sexuality, adolescence, education, health education, educational games, sex, violence, and sexually transmitted infections.

\section{Study protocol}

The game was initially sent to the SG in the same way as it occurred with adolescent players - by sending the game link via e-mail, which directs players to fill out a short registration, to create a password, choosing a codename and an avatar, for later access to the virtual environment of the game (Figure 1).

The previous contact with the game by the SG was decisive for the subsequent sending of the collection instrument, built on the Google Forms online platform. The form was made available by sending a formal invitation to participate in the survey, plus information on how to complete it, and with an estimated time of 30 minutes.

The data collection instrument was composed of five categories, subdivided into 85 variables, based on parameters pointed out in studies assessing educational electronic games ${ }^{(8-10)}$ as:

- Category 1 - Technical and esthetic aspects: with 33 variables related to language, graphic elements, ambience, design, accessibility, styles, and shapes;

- Category 2 - Dynamics: with 16 variables in relation to the presentation of the game, the interaction and contribution of players, the problem situations and the progression in the game; 


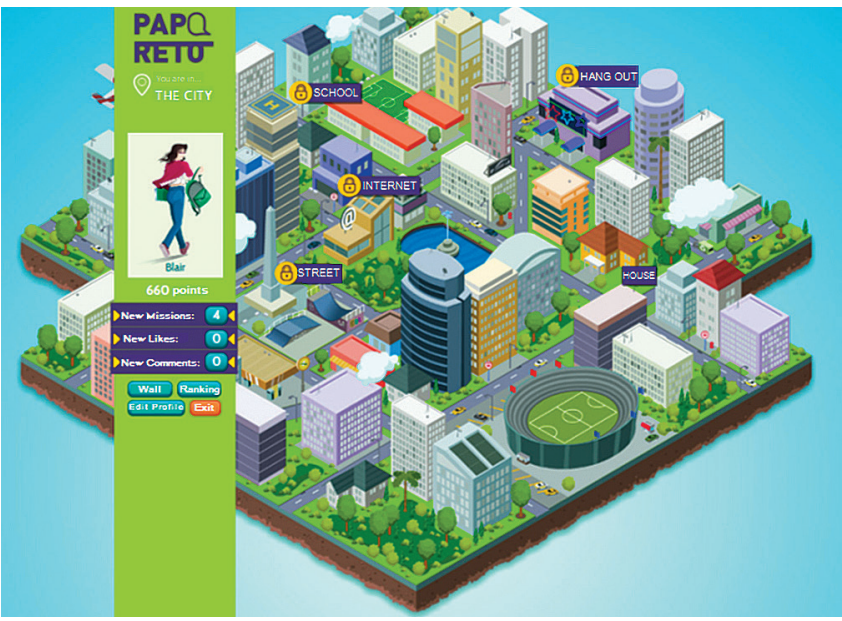

Figure 1 - Papo Reto platform

- Category 3 - Playfulness: with seven variables on originality, each player's capacity for involvement, entertainment and provocation of the game;

- Category 4-Content: with 10 variables related to the themes established by setting, relevance of content, language clarity and adequacy;

- Category 5 - Pedagogical potential: with 19 variables concerning levels of difficulty, learning potential, ability to problematize and instigate critical-reflective positioning, autonomy and invention.

Each variable was assessed following the Likert scale, with three possible responses: "Adequate", "Partially Adequate" and "Inadequate".

\section{Analysis of results and statistics}

The data were treated using the Stata software, version 14.0. Frequencies and proportions were used to characterize the judges. For each category of the form, the Cronbach's Alpha coefficient (a) was calculated, which expresses the internal reliability of the collection instrument classified as low ( $a \leq 0.30)$, moderate $(0.30$ $<a \leq 0.75)$, high $(0.75<a \leq 0.90)$ and very high $(a>0.90)^{(11)}$.

For the variables, Content Validity Index (CVI) was calculated, which expresses the agreement between the evaluators regarding the adequacy of the analyzed variables ${ }^{(12)}$. In assessing items individually, the authors point out the need to consider the number of judges ${ }^{(13)}$. In the case of 5 or less, everyone's agreement is required, with a $C V I=1$. For 6 or more evaluators, a $C V I$ of not less than 0.75 is recommended ${ }^{(13)}$.

\section{RESULTS}

In Table 1, SG characterization, there is a predominance of nurses (75\%) and professors (91.66\%). The maximum degree was approximately $67 \%$ for $\mathrm{PhD}$ and $33 \%$ for postdoc. The time of experience in the main occupation area was more than 10 years for $50 \%$ of the judges. The others revealed an interval between 1 and 10 years.

In the grouping of evaluators according to their main occupation areas, in Table 1, there is a division into three groups of four judges according to the areas mentioned in the collection instrument as sexuality, adolescence, education, health education, educational games, sex, violence, and sexually transmitted infections.

Table 1 - Characterization of judges, Belo Horizonte, Minas Gerais, Brazil, 2016-2017

\begin{tabular}{|c|c|c|}
\hline Variables & $\mathbf{N}^{\circ}$ & $\%$ \\
\hline \multicolumn{3}{|l|}{ Academic training } \\
\hline Nursing & 9 & 75.00 \\
\hline Psychology & 1 & 8.33 \\
\hline Pedagogy & 1 & 8.33 \\
\hline Biological Sciences & 1 & 8.33 \\
\hline \multicolumn{3}{|l|}{ Position } \\
\hline Professor & 11 & 91.66 \\
\hline Researcher & 1 & 8.33 \\
\hline \multicolumn{3}{|l|}{ Academic degree } \\
\hline $\mathrm{PhD}$ & 8 & 66.67 \\
\hline Postdoc & 4 & 33.33 \\
\hline \multicolumn{3}{|l|}{ Time of experience } \\
\hline$>10$ years & 6 & 50.00 \\
\hline$\geq 5$ to $\leq 10$ years & 3 & 25.00 \\
\hline$\geq 3$ to $<5$ years & 2 & 16.67 \\
\hline$\geq 1$ to $<3$ years & 1 & 8.33 \\
\hline$<1$ year & 0 & - \\
\hline \multicolumn{3}{|l|}{ Main occupation areas } \\
\hline $\begin{array}{l}\text { SG } 1 * \text { - Education, Adolescence, Sexuality and } \\
\text { Sexually Infected Transfers }\end{array}$ & 4 & 33.33 \\
\hline SG $2^{* *}$ - Health Education and Educational Games & 4 & 33.33 \\
\hline $\begin{array}{l}\text { SG } 3^{* * *} \text { - Education, Adolescence, Gender and } \\
\text { Violence in Intimate Relations }\end{array}$ & 4 & 33.33 \\
\hline
\end{tabular}

Of the 85 variables analyzed, $3 \%$ of the "I don't know" responses were excluded from the list, $2 \%$ concerning the category Technical and esthetic aspects, 3\% concerning Dynamics, $8 \%$ concerning Playfulness, $5 \%$ concerning Content and $5 \%$ concerning Educational potential.

In Table 2, in which the a coefficient values are presented by categories, it is noted that Playfulness showed very high reliability, with $a=0.95$, while the others expressed a highly reliable alpha, with $a \geq 0.79$.

Chart 1 shows the variables validated with $C V I=1$, divided by categories and by SG. In the category Technical and esthetic aspects [of the game], of the 33 variables assessed, 8 were validated by the three SG, 20 by two and 5 by one. In the Dynamics [of the game], of the 16 variables, 15 were validated, being seven by the three SG, four by two and four by one. In the Playfulness [of the game], of the seven variables, four were validated by two SG and three by one. In the Content [of the game], of the 10 variables assessed, three were validated by the three SG, six by two and one by one. In the Pedagogical potential [of the game], of the 19 variables, six were validated by the three SG, seven by two and six by one.

Table 2 - Reliability index Cronbach's Alpha (a) by categories, Belo Horizonte, Minas Gerais, Brazil, 2016-2017

\begin{tabular}{lc}
\hline Category & Cronbach's Alpha (a) \\
\hline Technical and esthetic aspects & 0.82 \\
Content & 0.79 \\
Dynamics & 0.81 \\
Playfulness & 0.95 \\
Pedagogical potential & 0.89 \\
\hline
\end{tabular}


Chart 1 - Variables validated by categories and by number of Specific Groups, Belo Horizonte, Minas Gerais, Brazil, 2016-2017

\begin{tabular}{|c|c|c|}
\hline Category & SG number* & Validated Variables \\
\hline \multirow{4}{*}{$\begin{array}{l}\text { Technical } \\
\text { and esthetic } \\
\text { aspects }\end{array}$} & 3 & $\begin{array}{l}\text { Access to the game via internet (SG 1,2 and 3)**; Opening sequence of the settings (SG 1, } 2 \text { and 3); Use of open } \\
\text { questions (SG 1,2 and 3); Format of presentation of the ranking of the most scored players (SG 1,2 and 3); Access to } \\
\text { comments received (SG 1,2 and 3); Name of the tab "Where to get help?" (SG 1,2 and 3); Possibility of players being } \\
\text { able to denounce others and language used (SG 1,2 and 3). }\end{array}$ \\
\hline & 2 & $\begin{array}{l}\text { Name of the game (SG } 2 \text { and 3) **; Ease of use for the first access user (SG } 2 \text { and 3); Possibility for the user to participate } \\
\text { in the game without having advanced technological knowledge (SG } 2 \text { and 3); Presentation of the game's homepage (SG } \\
2 \text { and 3); Use of graphic elements, colors and layout of the game's initial screen (SG } 2 \text { and 3); Constitution of the Game } \\
\text { map in five settings (SG } 2 \text { and 3); Use of a"Usage Guide" in which all game rules are specified (SG } 2 \text { and 3); Use of closed } \\
\text { questions (SG } 1 \text { and 3); Design and designation of medals (SG } 2 \text { and 3); Design and denomination of the trophies (SG } 2 \\
\text { and 3); Use of a wall with the presentation of collaborations (SG } 2 \text { and 3), trophies and medals of players; Using the "Get } \\
\text { it?" tab as a consultation space for players (SG } 1 \text { and 3); Presentation format of the "Get it?" tab (SG } 1 \text { and 3); Denomination } \\
\text { "Get it?" (SG } 1 \text { and 3); Using the "Where to get help?" tab as a space where phones and addresses of support services for } \\
\text { players are made available (SG } 1 \text { and 3); Presentation format of "Where to get help?" (SG } 1 \text { and 3); Possibility for players to } \\
\text { be able to communicate with the game administrators through the "Contact Us" tab (SG } 1 \text { and 3). }\end{array}$ \\
\hline & 2 & $\begin{array}{l}\text { Possibility of players being totally blocked from the game, after being denounced by at least three different players and } \\
\text { after assessment by the game administrators (SG } 1 \text { and } 3)^{* *} \text {; Possibility for players to have their answer, comment or } \\
\text { situation posted automatically blocked in the game, after the complaint of at least three different players (SG } 1 \text { and 3); } \\
\text { Game style for the target audience (SG } 2 \text { and 3). }\end{array}$ \\
\hline & 1 & $\begin{array}{l}\text { Ability of the game to be run on different brands, models and computer configurations (SG 1)**; Avatars that are used } \\
\text { in the game (SG 2); Information presented in the "How to Play" tab (SG 2); How to display players on the screen (SG 2); } \\
\text { and Use of the "Indicate a school" tab, in which players can indicate a school for making the game available (SG 3). }\end{array}$ \\
\hline \multirow{3}{*}{ Dynamics } & 3 & $\begin{array}{l}\text { Player be represented by an avatar and be identified by a nickname, of their choice (SG 1,2 and 3)**; Division of the } \\
\text { game by settings, for a progressive and in-depth approach to themes related to sexuality (SG 1,2 and 3); Use of pre- } \\
\text { defined themes related to each setting, with the exception of the street (SG 1,2 and 3); Possibility for players to be able } \\
\text { to return and play in the settings already conquered (SG 1,2 and 3); Punctuation to be obtained by the largest number } \\
\text { of problem situations answered and by the interaction with peers (SG 1,2 and 3); Possibility for players who conquered } \\
\text { certain missions in the game and become collaborators, being able to post their own situations in the game (SG 1,2 } \\
\text { and 3); and Use of a wall that summarizes the users' performance (SG 1,2 and 3). }\end{array}$ \\
\hline & 2 & $\begin{array}{l}\text { The street is the only free setting for posting any topic (SG } 2 \text { and 3)**; Possibility for players to be able to respond or assess the } \\
\text { situations, according to their interest (SG } 2 \text { and 3); Possibility of the likes received granting a higher score in the game (SG } 1 \text { and } \\
\text { 2); and Use of a ranking, which reveals the eleven most scored players and the position of the logged player (SG } 2 \text { and } 3 \text { ). }\end{array}$ \\
\hline & 1 & $\begin{array}{l}\text { Game format with presentation of problem situations, responses, comments and the options I liked, I didn't like or I } \\
\text { didn't understand (SG 3)**; Possibility for players to be able to change his nickname and avatar in the game's profile } \\
\text { tab, at any time during the game (SG 3); Form of release and access to the game's settings according to the players' } \\
\text { score (SG 2); and Impossibility of players having the right to reply and rejoice to the comments received (SG 1). }\end{array}$ \\
\hline \multirow[t]{2}{*}{ Playfulness } & 2 & $\begin{array}{l}\text { Ability of the adolescent to be involved with the game (SG } 2 \text { and } 3 \text { ) }{ }^{* *} \text {; Originality of the game (SG } 2 \text { and } 3 \text { ); Ability to } \\
\text { promote interaction among players (SG } 2 \text { and 3); and Provocative ability of the game to address the theme of sexuality } \\
\text { in adolescence (SG } 2 \text { and 3). }\end{array}$ \\
\hline & 1 & $\begin{array}{l}\text { Game entertainment capacity (SG 2)**; Ability to cause tension, anxiety or irritation in players (SG 2); and Ability to } \\
\text { instigate the first places in the game (SG 3). }\end{array}$ \\
\hline \multirow{3}{*}{ Content } & 3 & $\begin{array}{l}\text { Themes established for the school setting (SG 1,2 and 3)**; Themes established for the internet setting (SG 1, } 2 \text { and 3); } \\
\text { Relevance of the content of the problem situations for addressing the topic of sexuality (SG 1,2 and 3). }\end{array}$ \\
\hline & 2 & $\begin{array}{l}\text { Themes established for the house setting (SG } 2 \text { and 3)**; Themes established for the hang out setting (SG } 1 \text { and 2); Clarity of } \\
\text { the situations presented in the game (SG } 2 \text { and 3); Adequacy of the game language to adolescents (SG } 2 \text { and 3); Contents of } \\
\text { the "Where to get help?" tab (SG } 2 \text { and 3) and Contextualization of the game with the adolescent's reality (SG } 2 \text { and 3). }\end{array}$ \\
\hline & 1 & Contents of the "Get it?" tab (SG 3) \\
\hline \multirow{3}{*}{$\begin{array}{l}\text { Pedagogical } \\
\text { potential }\end{array}$} & 3 & $\begin{array}{l}\text { Ability of the game to enable learning, through interaction among peers (SG } 1,2 \text { and } 3)^{* *} \text {; Ability of the game to } \\
\text { provide immediate feedback to players (SG 1,2 and 3); Ability of the game to instill the players' curiosity (SG 1,2 and 3); } \\
\text { Critical-reflective potential of the game to address violence in affective-sexual relationships (SG 1,2 and 3); Ability of } \\
\text { autonomy given to the adolescent in the game (SG 1,2 and 3) and Practical application of the content of the game in } \\
\text { educational activities aimed at the adolescent public (SG 1,2 and 3). }\end{array}$ \\
\hline & 2 & $\begin{array}{l}\text { Increasing levels of difficulty in fulfilling the game's missions (SG } 2 \text { and 3)**; Permissiveness to create problem situations, } \\
\text { created by players (SG } 2 \text { and 3); Ability of the game to simulate situations that resemble the reality of adolescents (SG } 2 \\
\text { and 3) (data not shown); Simulation skills enable the experience of difficult situations to be addressed in the daily lives of } \\
\text { adolescents (SG } 2 \text { and 3); Critical-reflective potential of the game for addressing sex in the field of sexuality (SG } 1 \text { and 3); } \\
\text { Ability to break with pre-conceived knowledge in the field of sexuality (SG } 1 \text { and 3); and Ability of the game to promote } \\
\text { challenging situations in raising hypotheses, reflections and exchanges (SG } 1 \text { and 3). }\end{array}$ \\
\hline & 1 & $\begin{array}{l}\text { Ability of the game to support learning through situations that resemble the reality of adolescents (SG } 3 \text { )**; Ability of } \\
\text { the game to motivate the search for new knowledge about sexuality (SG 3); Critical-reflective potential of the game } \\
\text { to address the topic of sexuality (SG 3); Potentiality of the game to problematize issues of sex, sexuality and violence } \\
\text { in adolescence (SG 3); Ability to (re) construct knowledge that involves the topic of sexuality (SG 3); and Ability of the } \\
\text { game to provide innovative and enriching educational experiences (SG 3). }\end{array}$ \\
\hline
\end{tabular}

Note: *Number of Specific Group/Details of the variables validated by number of Specific Group; **The information in parentheses corresponds to each Specific Group by validated variable. 


\section{DISCUSSION}

In the assessment of Technical and esthetic aspects, first category analyzed, there was a similarity with other games validation studies regarding the importance of non-textual elements, especially images $^{(13-14)}$. Image is considered an aid to the understanding of a given subject, as it requires less effort to understand it ${ }^{(13)}$. They are also pointed out as important resources for the communication of scientific ideas, contributing to their intelligibility, to the constitution of ideas and their contextualization, besides being self-explanatory, overcoming language barrier ${ }^{(14)}$.

On the game platform, the relationship between textual and nontextual elements is present mainly in problem situations, illustrated by images that seek to portray in a realistic and attractive way all the situations presented. Graphic elements, colors and layout were also used both on the home screen and in the design of trophies and medals, all of which were validated by two SG. The graphic design of the avatars was validated only by SG 2 . This assessment was associated with the limited number of nine avatars possibilities, with the option for three skin colors - white, mixed-race and black - and one of them in the shape of a "soul" without the definition of sex. The absence of alternatives with variations of the body and face biotype or the possibility of creating your own avatar were limited by the lack of financial resources for this purpose.

Concerning Dynamics, the second category analyzed, studies emphasize the importance of the game promoting the players' autonomy through the freedom to move through the spaces of the game and to obtain feedback on its results ${ }^{(15)}$. All these aspects were validated by the three SG.

In relation to Dynamics, in the study of validation of the game Aprendendo a Viver (freely translated as Learning to Live), about sexuality, because it is a real environment, the initial discomfort due to the players' exposure was explained as a limiting factor ${ }^{(16)}$. The fact that players present themselves in a virtual environment and are represented by an avatar was a choice previously established to their creation, aiming to reduce constraints, bullying and facilitate the approach to the contents. It was also intentional to allow dialogue about sex and sexuality ${ }^{(5)}$ without being attached to definitive or pre-established characteristics. In the game, players can change their code and avatar whenever and as often as they want.

In the Dynamics, 15 of the 16 variables were validated. The only one not validated refers to the fact "players cannot change an answer already sent". The game is a simulator of realities that aims to provide learning through interaction among peers. This interaction capacity is pointed out as fundamental for the learning provided in simulation games ${ }^{(15)}$. The detection of this process of expanding experiences and opening up to the acquisition of new ways of thinking, feeling and acting was one of the bases for analyzing the potential of the game and which led to the impossibility of changing the posted answers. On the game platform, reports are issued that depict the history of the responses of each player, which can be analyzed according to age, educational institution and other aspects that can assist in understanding the path taken by each player.

As for Playfulness, third category analyzed, studies reinforce the relevance of the players' displacement from the demanding academic reality to fun moments, maintaining the restless spirit of playfulness ${ }^{(17-18)}$. This impasse between the combination of the fun component and the educational proposition, without overlapping one over the other ${ }^{(3)}$, was the main challenge faced in creating the game. The discordant results among SG, as in the case of the "entertainment of the game" and "instigating the first positions in the game" capacity, validated by only one SG, reinforces the difficulty of the intersection between the playful dynamics and the educational activity. The availability of a ranking of the most scored and the bet on provocative approaches to problem situations and the ability to interact were the strategies used to drive the playful, although they still need greater investment from the playful to continue production in this area.

On Content, fourth category, research highlights the ability of content and context to provide behavioral changes in educational games $^{(19)}$. The learning path was guided by another aspect, in which players are not directed to a pre-established response or a certain behavior. The favor for the construction of knowledge is found in the active role of players, by a shared action, far from the norm for a behavior considered ideal or healthy. Such aspects, contemplated in the dynamic category of the game, were validated by SG 2 and 3.

Concerning Content, language adequacy to the target audience is pointed out as something to always be considered ${ }^{(20-21)}$. Most of the situations presented were extracted from real life, with the use of a concise and simplified language aiming at greater proximity with the adolescents. In this case, both language adequacy to the public and game contextualization to the adolescent's reality, in addition to the clarity of the situations were validated by SG 2 and 3 .

Contents were established with the definition of themes for each setting. The street, the last stage of the game, corresponds to the only space in which there are no pre-established themes. The fact that the game has specific themes for each setting, except the street, was defined at the time of the game's creation, in view of directing the level and type of approach for each setting. The adolescent, when acquiring the status of "collaborator" in the game, based on a certain score, will be able to post their own situations, having to previously choose the theme through a list of approximately 23 subjects per setting. The contents relevant to the school and the internet were validated by the three SG. Those at home were validated by SG 2 and 3, and those at school by SG 1 and 2 .

Concerning Pedagogical potential, fifth and last category analyzed, authors point to the importance of an educational activity based on dialogicity and active participation of adolescents in the construction of knowledge ${ }^{(22-23)}$. This potentiality was linked to the possibility of interaction among players, betting on the construction, deconstruction and reconstruction of knowledge provided by a critical-reflective positioning, encouraged by the problem situations presented. This potential is also expected due to the unpredictability of responses, comments and situations posted by employees, bringing the possibility of cracks in hegemonic and often blaming discourses in approaches to sexuality.

\section{Study limitations}

It is believed that the fact that the evaluators are experts in diversified areas may have restricted the analysis of certain categories, considering the possible difficulties when assessing the Game from different perspectives that go beyond their areas of 
expertise. This fact gains more strength, by identifying the presence of "I don't know" responses in all the categories assessed, especially those concerning Playfulness (8\%), Content (5\%) and Pedagogical potential (5\%). It is noteworthy, however, that this same fact reveals its potential, by allowing greater diversity in the analysis. The extension of the game with five settings and the computation of 130 problem situations can also represent a limiting factor, based on the fact that not all judges were able to go through all the settings, themes and content of the game for analysis.

\section{Contributions to the field}

This study contributes to the advancement of the discussion on the topic of sexuality in adolescence, enabling the production of new realities, including the different ways of existing. The game reveals itself as a problematic aspect, being able to prioritize essential aspects of the content covered, such as the mobilization of players in relation to their desires and experiences. Finally, the possibility of applying the game by professionals from different areas is highlighted. It may also be used for professional qualification, especially for nurses, considering its history of educational actions carried out in primary care and in partnership with educational institutions.

\section{CONCLUSIONS}

Validation of the game Papo Reto regarding technical and esthetic aspects, dynamics, playfulness, content and pedagogical potential for addressing the theme "sexuality in adolescence" was obtained in 84 of the 85 variables. Validation by judges expressed the adequacy of the game in relation to the analyzed categories, which was evidenced by the internal consistency of the collection instrument expressed by Cronbach's Alpha.

The breadth of the variables used allowed game assessment in various aspects for validation. The diversity of validation methods and the areas of activity of the SG contributed to greater reliability to the results, assessing the legitimacy of the game.

The game was validated as to its pedagogical potential for addressing the theme "sexuality in adolescence", revealing itself capable of providing reflection and critical positioning, being able to be applied to address sexuality with adolescents aged 15 to 18 years.

It is noteworthy that the intersection between fun and the educational process was the main challenge found in the production of Papo Reto. In the final product, the sovereignty of learning over play is still observed. Although the game has been validated in all categories, variations in the CVI reveal fundamental aspects that are expected to be overcome in other research on the topic.

\section{FUNDING}

This research was financed by Fundação de Amparo à Pesquisa de São Paulo (FAPESP - freely translated as Research Support Foundation of the State of São Paulo) and Fundação de Amparo à Pesquisa de Minas Gerais (FAPEMIG - freely translated as Research Support Foundation of the State of Mind Gerais).

\section{REFERENCES}

1. Johnson S. Tudo que é ruim é bom para você: como os games e a TV nos tornam mais inteligentes. Brasil: Zahar; 2012.

2. Brougère G. Jogo e educação. Porto Alegre: Artes Médicas; 1998.

3. Pires MRGM, Guilhem D, Göttems LBD. The (in)dica-SUS game: a strategy of game-based learning on the unifield health system. Texto Contexto Enferm. 2013;22(2):379-88. doi: 10.1590/S0104-07072013000200014

4. Gazzinelli MF, Souza V, Fonseca RMGS, Fernandes MM, Carneiro ACLL, Godinho LK. Educational group practices in primary care: interaction between professionals, users and knowledge. Rev Esc Enferm USP. 2015;49(2):284-91. doi: 10.1590/0104-07072017000260016

5. Souza V, Gazzinelli MF, Soares NA, Fernandes MM, Oliveira RNG, Fonseca RMGS. The game as strategy for approach to sexuality with adolescents: theoretical-methodological reflections. Rev Bras Enferm. 2017;70(2):394-401. doi: 10.1590/0034-7167-2016-0043

6. Deleuze G. Que é um dispositivo? In: Balbier E, Deleuze G, Dreyfus H, Frank M, Glücksmann. Michel Foucault, filósofo. Barcelona: Gedisa, 1990. p. $155-63$.

7. Phillips AC, Lewis LK, McEvoy MP, Galipeau J, Glasziou P, Moher D, Tilson JK, Williams MT. Development and validation of the guideline for reporting evidence-based practice educational interventions and teaching (GREET). BMC Med Educ. 2016;16(1):237. doi: 10.1186/ s12909-016-0759-1

8. Alves JC, Sampaio LC, Carvalho MFGS, Aldeia ACPG, Guelpeli MVC. Metodologia para Avaliação de Software de Autoria como uma Ferramenta Computacional para auxílio no Desenvolvimento de Conteúdos Didático-Pedagógicos [Internet]. Informática na Educação. 2004 [cited 2019 Jan 20]. 2. Available from: http://nlx.di.fc.ul.pt/ guelpeli/Arquivos/Artigo16.pdf

9. Medeiros MO, Schimiguel J. Uma Abordagem para avaliação de jogos educativos: ênfase no ensino fundamental. In Brazilian Symposium on Computers in Education. 2012;23(1). doi: 10.22456/1679-1916.36378

10. Almeida TG, Vasconcelos EL, Trindade RFC, Comassetto I, Ferreira AS, Lopes RF. Validação de material educativo como ferramenta pedagógica sobre métodos contraceptivos para adolescentes. Rev Enferm UFPE [Internet]. 2016 [cited 2019 Jan 20];10(12):4696-700. Available from: https://periodicos.ufpe.br/revistas/revistaenfermagem/

11. Monteiro GTR, Hora HRM. Pesquisa em saúde pública: Como desenvolver e validar instrumento de coleta de dados. Curitiba: Appris; 2013.

12. Wood GLB, Haber J. Pesquisa em Enfermagem: métodos, avaliação crítica e utilização. 4 ed., Brasil. Guanabara Koogan. 2001. 
13. Alexandre NMC, Coluci MZO. Validade de conteúdo nos processos de construção e adaptação de instrumentos de medidas. Ciên Saúde Coletiva. 2011;16(7):3061-68. doi: 10.1590/S1413-81232011000800006

14. Moura ERF, Bezerra CG, Oliveira MS, Damasceno MC. Validação de jogo educativo destinado à orientação dietética de portadores de diabetes mellitus. Rev. APS. 2008;11(4):435-43. Available from: http://ojs2.ufjf.emnuvens.com.br/aps/article/view/14153/7658

15. D'Avila CG, Puggina AC, Fernandes RAQ. Construction and validation of an educational game for pregnant women. Esc Anna Nery. 2018;22(3). doi: 10.1590/2177-9465-EAN-2017-0300

16. Smale E, Overmans T, Jeuring J, Grint LV. The effect of simulations and games on learning objectives in tertiary education: a systematic review. International Conference on Games and Learning Alliance. 2015;506-16. doi: 10.1007/978-3-319-40216-1_55

17. Silva GR, Amâncio JM, Carlos LA. Uma discussão de forma lúdica, sobre a sexualidade e métodos preventivos-contraceptivos com adolescentes da rede estadual de ensino. Rev Ibero-Am Est Educ. 2014;9(3):668-79. doi: 10.21723/riaee.v9i3.7085

18. Pires MRGM, Göttems LBD, Silva LVS, Carvalho PA, Melo GF, Fonseca RMGS. Development and validation of an instrument for evaluating the ludicity of games in health education. Rev Esc Enferm USP. 2015;49(6):981-90. doi: 10.1590/S0080-623420150000600015

19. Soares AN; Gazzinelli MF; Souza V, Araújo LHL. Role Playing Game (RPG) on nursing undergraduate course: educational potentials. Rev Eletrôn Enferm. 2016;18:1-10. doi: 10.5216/ree.v18.37672

20. Levine, MH, Vaala SE. Games for learning: vast wasteland or a digital promise? Wiley O Lib. 2013;139:71-82. doi: 10.1002/cad.20033

21. Silva AKC, Oliveira KMM, Coelho MMF, Moura DJM, Miranda KCL. Development and validation of an educational game for adolescents about breastfeeding. Rev Baiana Enferm. 2017;31(1):e16476. doi: 10.18471/rbe.v31i1.16476

22. Silva RA, Ximenes LB, Cruz AG, Serra MAAO, Araújo MFM, Andrade LM, Studart RMB, Carvalho MF. Actividad sexual en la lesión medular: construcción y validación de libreta educativa. 2018; 31(3):255-64. doi: S0103-21002018000300255.

23. Sousa MG, Oliveira EML, Coelho MMF, Miranda KCL, Henriques ACPT, Cabral RL. Validation of educational game for adolescents about the sexuality topic. Rev Pesqui: Cuid Fundam. 2018;10(1):203-9. doi: 10.9789/2175-5361.2018.v10i1.203-209 